\title{
Siedmiu braci machabejskich z Czwartej Księgi Machabejskiej jako typ Chrystusa. Próba zastosowania egzegezy typologicznej do tekstu Czwartej Księgi Machabejskiej²
}

Już od czasów patrystycznych istnieje głębokie przekonanie, że dla chrześcijan objawienie jest tożsame z Chrystusem. Skoro bowiem Chrystus jest Słowem Boga, a o Biblii mówimy, że również jest Słowem Boga, to niewątpliwie objawienie w całości dotyczy Jego osoby, objawienie zarówno zawarte w Starym, jak i w Nowym Testamencie. W tym ujęciu Stary Testament jako cały stanowi zapowiedź tego, co zrealizowało się w Nowym Testamencie. Innymi słowy całe starotestamentalne objawienie stanowi niejako proroctwo, w którym egzegeta, podążając nowotestamentalnymi tropami, odnajduje typy Chrystusa oraz rzeczywistości przynależnych do tak zwanej ,pełni czasów" (Ga 4,4) ${ }^{3}$. Na gruncie takiego rozumowania powstała w epoce patrystycznej egzegeza duchowa, która Stary Testament postrzegała właśnie jako zapowiedź nadejścia Chrystusa, Chrystusa natomiast - jako klucz do interpretacji ksiąg Starego Przymierza. Podstawą do takiej wykładni tekstów starotestamentalnych były między innymi wskazania zawarte w Nowym Testamencie, jak choćby to wyrażone przez apostoła Pawła: „A wszystko to przydarzyło się im [Żydom] jako zapowiedź

Ks. dr Grzegorz M. Baran, pracownik Katedry Pisma Świętego na Wydziale Teologicznym Sekcji w Tarnowie Uniwersytetu Papieskiego Jana Pawła II w Krakowie, mail: mariusz.grzegorz@wp.pl, ORCID: 0000-0002-4160-8907.

2 Koncepcja tego artykułu zrodziła się - można by rzec - pod wpływem lektury artykuł J. de la Potterie (Czytanie Pisma Świętego „w Duchu”: Czy możliwe jest obecnie patrystyczne czytanie Biblii?, tł. L. Balter, „Communio. Międzynarodowy Przegląd Teologiczny" 4 [1986], z. 3, 42-57), a także książki K. Bardskiego (Słowo oczyma Gołębicy. Metodologia symboliczno-alegorycznej interpretacji Biblii oraz jej teologiczne i duszpasterskie zastosowanie, Rozprawy Naukowe 3, Warszawa 2007).

3 Zob. H. Crouzel, Orygenes, tł. J. Margański, Kraków 2004, 102-104. 
rzeczy przyszłych, spisane zaś zostało ku pouczeniu nas, których dosięga kres czasów" (1Kor 10,11) . Idąc po tej myśli, niektórzy z wczesnochrześcijańskich pisarzy-egzegetów zaczęli poszukiwać znaczenia duchowego w najdrobniejszych nawet szczegółach starotestamentalnych opowiadań ${ }^{5}$. Tego rodzaju interpretacja tekstów biblijnych ujawnia się między innymi w stosowanej wówczas egzegezie typologicznej, która łączy się dość ściśle z egzegezą alegoryczną.

W literaturze przedmiotu egzegeza typologiczna jest pojmowana jako szczególna metoda interpretowania Pisma Świętego, która w Starym Testamencie, w jego instytucjach, rytuałach, a także w opisach różnych wydarzeń, doszukuje się prefiguracji ${ }^{6}$ czy też „typów"7 rzeczywistości chrześcijańskich $^{8}$. „Typowi” Starego Testamentu odpowiada zatem ,antytyp" ${ }^{\text {" Nowego Testamentu }}{ }^{10}$.

Pierwszym przykładem egzegezy typologicznej, który uzyskał charakter wzorcowy w całym okresie patrystycznym, jest ,chrystologia «Adama»” apostoła Pawła, która streszcza się w zdaniu: „On to jest typem (týpos) Tego, który miał przyjść" (Rz 5,14). Pisarze wczesnochrześcijańscy, stosując egzegezę typologiczną, pragnęli wykazać jedność planu Bożego poprzez stulecia i wyższość Nowego Przymierza nad Starym, który był jedynie zarysem, zapowiedzią ${ }^{11}$. W tym względzie typologia, posiadająca wymiar horyzontalny, różni się od egzegezy alegorycznej ${ }^{12}$, którą charakteryzuje się często jako „wykładnię przebiegającą pionowo”, czyli

4 Por. Crouzel, Orygenes, s. 97-102.

5 Transparentnym przykładem takiego podejścia są pisma Orygenesa. Zob. Crouzel, Orygenes, s. 106.

6 Zob. np. Melito Sardensis, Homilia de Pascha 19, 5.

7 Zob. np. Iustinus, Dialogus cum Tryphone 40-42.

8 Zob. M. Simon, Cywilizacja wczesnego chrześcijaństwa, tł. E. Bąkowska, Warszawa 1992, 465. Por. M. Domaradzki, Między alegoria a typologia. Uwagi o hermeneutyce Orygenesa, PrzRel 239 (2011) z. 1, 20.

9 Zob. 1P 3,21. W takim ujęciu „typ (ho týpos)” jest znakiem, zapowiedzą, ,antytyp (ho antítypos lub tò antítypos)" natomiast oznacza rzeczywistość zapowiadaną. Por. S. Hahn, Moc stowa w liturgii. Od tekstu pisanego do żywego słowa liturgii, tł. P. Blumczyński, Kraków 2010, 33-34.

10 Zob. B. McNeil, Typologia, w: Stownik hermeneutyki biblijnej, red. R.J. Coggins - J.L. Houlden, tł. B. Widła, Warszawa 2005, 894. Por. J.K. Pytel, Objaśnienie sensu biblijnego w Kościele (Hermeneutyka), Gniezno 1996, 35-36.

11 Zob. McNeil, Typologia, s. 894.

12 Egzegezę alegoryczną określa się ogólnie jako metodę interpretacji, która polega na doszukiwaniu się pod dosłownym znaczeniem tekstu drugiego, przenośnego znaczenia, które - ujawniając jakiś głębszy sens moralny lub filozoficzny - nierzadko unieważnia sens dosłowny. Zob. Simon, Cywilizacja wczesnego chrześcijaństwa, s. 389. 
wertykalnie, ponieważ przedstawia ona ,ponadczasowe związki między obrazami a ich symbolami" 13 .

Egzegeza typologiczna zatem miała na celu potwierdzenie jedności obu Testamentów oraz wykazanie, że Stary Testament spełnia się w Jezusie Chrystusie. Wymownie o tym pouczył św. Ireneusz, stwierdzając: „,...] ukrytym w Pismach skarbem jest rzeczywiście Chrystus, ponieważ za pomocą typów i przenośni wskazywało się [w nich na Niego] (absconsus vero in Scripturis thesaurus Christus, quoniam per typos et paraboles significabatur [hóti diá týpōn kaì parabolốn esēmaíneto])"14.

Tego rodzaju podejścia do interpretacji Pisma Świętego nie wykluczają aktualne orzeczenia Magisterium Kościoła, czego przykładem jest stwierdzenie zawarte w Konstytucji Dogmatycznej Dei Verbum: „Ekonomia Starego Testamentu zmierzała nade wszystko ku temu, aby przygotować przyjście Chrystusa, Odkupiciela wszystkich ludzi, oraz mesjańskiego królestwa, proroczo je zapowiedzieć (por. $Ł k 24,44$; J 5,39; 1P 1,10) i wyrazić je $\mathrm{w}$ obrazach typicznych (et in variis typis significaret) (por. 1Kor $10,11)^{\prime \prime 15}$.

Tego rodzaju podejście można by (jako pewien eksperyment) zastosować również do Czwartej Księgi Machabejskiej. Na wstępie należy jednak zaznaczyć, że Czwarta Księga Machabejska nie przynależy do katolickiego kanonu biblijnego ${ }^{16}$, gdyż została zakwalifikowana do zbioru apokryfów Starego Testamentu. Podobnie jest w tradycji prawosławnej i protestanckiej: w wydaniach prawosławnych bowiem uwzględniana bywa jako dodatek, $\mathrm{w}$ protestantyzmie natomiast jest umieszczana albo pośród pseudoepigrafów, albo wraz z księgami deuterokanonicznymi wśród „Apokryfów”17. Niemniej jednak od starożytności cieszy się pewnym poszanowaniem $\mathrm{w}$ środowiskach chrześcijańskich. Wyrazem tego jest fakt, że tekst księgi zachował się w wielu rękopisach LXX, w tym w głównych kodeksach majuskułowych, czyli w Kodeksie Synajskim (IV wiek) i Kodeksie Aleksandryjskim (V wiek) oraz Kodeksie Venetus (VIII/

13 Zob. Domaradzki, Między alegoria, s. 19-20.

14 Irenaeus, Adversus haereses, 4, 26, PG 7,1052B (tł. własne).

15 Konstytucja Dogmatyczna o Objawieniu Bożym „Dei Verbum”, 15, w: Sobór Watykański II. Konstytucje, Dekrety, Deklaracje. Tekst lacińsko-polski, Poznań 2008, 552-555.

16 Z rzadka jednak Czwarta Księga Machabejska pojawia się w starożytności na listach kanonu. Zob. H.-J. Klauck, 4. Makkabäerbuch, Jüdische Schriften aus hellenistisch-römischer Zeit III/6, Gütersloh 1989, 677-678.

17 Zob. M. Wojciechowski, Apokryfy z Biblii greckiej. 3 i 4 Księga Machabejska, 3 Księga Ezdrasza oraz Psalm 151 i Modlitwa Manassesa, Rozprawy i Studia Biblijne 8, Warszawa 2001, 110. 
IX wiek). Występuje także w ponad dwudziestu skatalogowanych dotąd minuskułach, w czterdziestu menologiach, a także w niektórych rękopisach dzieł Józefa Flawiusza. Na uwagę zasługuje fakt, że wraz z innymi księgami greckimi była poddana tym samym recenzjom: recenzji Lucjana (1) oraz recenzji q. To z kolei stanowi dowód na dość wczesne włączenie tekstu Czwartej Księgi Machabejskiej do kolekcji ksiąg LXX ${ }^{18}$. Stąd też współczesne wydanie krytyczne LXX zawiera również Czwarta Księge Machabejska ${ }^{19}$. Mając na uwadze szeroko wśród uczonych dyskutowaną kwestię natchnienia tekstu LXX (przy czym są głosy za pewną formą jej natchnienia $)^{20}$, można pokusić się nadto o stwierdzenie, że powszechna obecność Czwartej Księgi Machabejskiej w LXX - również i w tej perspektywie - przyczynia się do wzrostu jej autorytetu. Należy także dodać, że po tekst Czwartej Księgi Machabejskiej sięgali w swym nauczaniu Ojcowie Kościoła ${ }^{21}$, co świadczy o jej znaczeniu w epoce patrystycznej.

Warto jeszcze, tytułem wstępu, poświęcić nieco uwagi charakterystyce samej Czwartej Księgi Machabejskiej. Jakkolwiek nie zwiera ona odniesień do Judy Machabeusza oraz jego braci (głównych bohaterów Pierwszej i Drugiej Księgi Machabejskiej), została jednak zaopatrzona przydawką „Machabejska”. Dokonało się to z pewnością z racji nawiązującego do Drugiej Księgi Machabejskiej opisu wydarzeń, a zwłaszcza męczeństwa starca Eleazara oraz siedmiu braci i ich matki. Chociaż owi męczennicy nie byli „Machabeuszami”, to jednak w liturgii i hagiografii chrześcijańskiej nazwano ich „braćmi machabejskimi”22. Oryginalnie Czwarta Księga Machabejska powstała w języku greckim. W ramach jej struktury można wyróżnić niejako dwie części: pierwsza dotyczy rozważań na temat panowania rozumu nad namiętnościami, druga zaś o charakterze narratywnym

18 Zob. Klauck, 4. Makkabäerbuch, s. 678-679. Por. Wojciechowski, Apokryfy, s. $97-98$.

19 Zob. np. Septuaginta. Id est Vetus Testamentum graece iuxta LXX interpretes. Duo volumina in uno, wyd. A. Rahlfs, Stuttgart 1982, 1157-1184.

20 Zob. np. K. Mielcarek, Ku nowej koncepcji natchnienia LXX, RT 48 (2001) z. 1, 5-25; P. Łabuda, Septuaginta - pragnienie poznania Biblii, TST 35 (2016) z. 1, 170-172.

21 Przykładem tego może być Mowa XV św. Grzegorza z Nazjanzu. Zob. G.M. Baran, Czwarta Księga Machabejska ttem Mowy XV św. Grzegorza z Nazjanzu, VoxP 37 (2017) t. 67, 41-70.

22 Świadczyć o tym może azjańska maniera retoryczna księgi, najbardziej zbliżona stylowi obecnemu w Azji Mniejszej. Również charakter Czwartej Księgi Machabejskiej jako swego rodzaju mowy pochwalnej na cześć męczenników, związanej z rocznicą ich śmierci oraz miejscem pochówku, może być świadectwem powstania księgi w kręgu antiocheńskim, z którym tradycyjnie był związany kult męczenników machabejskich w czasach późniejszych Zob. Wojciechowski, Apokryfy, s. 97. 
posiada cechy przekazu historycznego, w którym znajduje się relacja na temat próby profanacji świątyni jerozolimskiej przez pogańskiego dowódcę - Apoloniusza, jak również opis męczeństwa Eleazara oraz siedmiu braci i ich matki za czasów prześladowań ze strony Antiocha IV Epifanesa. Autor księgi jest nieznany. Z analizy tekstu Czwartej Księgi Machabejskiej można wywnioskować, że był nim pobożny Żyd, gorliwy obrońca przestrzegania wymogów Prawa Mojżeszowego. Pod względem wykształcenia widać u niego dość duże obeznanie z tekstami i teologią Starego Testamentu, a także solidne wykształcenie w retoryce i greckiej filozofii. Również nie można w sposób pewny określić miejsca powstania $C z w a r t e j$ Księgi Machabejskiej. Prawdopodobnie powstała w żydowskiej diasporze $\mathrm{w}$ Antiochii lub w jej kręgu ${ }^{23}$. Pewne problemy nastręcza także określenie jej czasu powstania. Jedni uczeni podają, że powstała w pierwszej połowie I wieku po Chrystusie ${ }^{24}$, inni zaś przyjmują, że została skomponowana pod koniec I wieku po Chrystusie, dokładnie pomiędzy 90 a 100 rokiem $^{25}$. Mając na uwadze podobieństwo pomiędzy Drugą Księgą Machabejską a Czwarta Księga Machabejska, naukowcy próbują także określić sposób zależności tychże ksiąg. Jedni uważają, że Druga Księga Machabejska była bezpośrednim źródłem dla Czwartej Księgi Machabejskiej, inni zaś, że obie mogły w sposób niezależny wykorzystać te same źródła ${ }^{26}$. Należy nadto zauważyć, że relacje o męczennikach w Czwartej Księdze Machabejskiej są dość mocno wystylizowane, stąd też historyczne podłoże jest nierozpoznawane. Czwarta Księga Machabejska dostarcza jednak ciekawych informacji na temat mentalności żyjącej w sferze kultury hellenistycznej diaspory żydowskiej kręgu antiocheńskiego ${ }^{27}$.

Po naszkicowaniu kilku uwag na temat samej metody egzegezy typologicznej oraz ogólnej charakterystyki Czwartej Księgi Machabejskiej przejdziemy teraz do realizacji celu, o którym jest mowa w tytule artykułu. Jak zostało zaznaczone w podtytule, będzie to swego rodzaju ,próba” zastosowania egzegezy typologicznej do tekstu Czwartej Ksiegi

23 Zob. Klauck, 4. Makkabäerbuch, s. 665-666; Wojciechowski, Apokryfy, s. 99100. Por. H. Anderson, 4 Maccabees. A New Translation and Introduction, w: The Old Testament Pseudepigrapha, vol. 2, red. J.H. Charlesworth, An Anchor Bible Reference Library, New York 1985, 533, 535.

24 Zob. D.A. de Silva, 4 Maccabees, Guides to Apocrypha and Pseudepigrapha, Sheffield 1998, 18.

25 Zob. Klauck, 4. Makkabäerbuch, s. 669.

26 Zob. Wojciechowski, Apokryfy, s. 102-103.

27 Zob. Wojciechowski, Apokryfy, s. 108. Por. G.M. Baran, Życie i śmierć Antiocha IV Epifanesa w przekazach pozabiblijnych i biblijnych. Historia i teologia, Tarnów 2015, 18-19. 
Machabejskiej. Głównym zamierzeniem tej „próby” natomiast będzie wykazanie, że siedmiu braci Machabejskich może być postrzeganych jako typ Chrystusa.Mając na uwadze fakt, że Czwarta Księga Machabejska nie przynależy do kanonu biblijnego, a więc nie stanowi tekstu natchnionego, podkreślamy, że podjęte zamierzenie jest „próbą”, którą w jakiś sposób usprawiedliwia „autorytet” księgi, o czym była mowa wyżej. Należy nadto raz jeszcze zaznaczyć, że - co zastało wyżej powiedziane - Czwarta Ksiega Machabejska powstała już po Chrystusie, a zatem w zastosowaniu do jej interpretacji egzegezy typologicznej wkrada się - można by rzec - niejako pewien ,anachronizm”. Stąd też podjęta tego rodzaju interpretacja Czwartej Księgi Machabejskiej tym bardziej zasługuje na dookreślenie mianem „próba”, którą w tym kontekście usprawiedliwia jednak fakt, że zawiera ona te same motywy, co relacjonująca wydarzenia z tak zwanego „kryzysu hellenistycznego” (175-164 r. przed Chrystusem) Druga Księga Machabejska, która najprawdopodobniej powstała w ostatnim ćwierćwieczu II wieku przed Chrystusem ${ }^{28}$ i przynależy do katolickiego kanonu ksiąg natchnionych.

\section{Siedmiu młodzieńczych braci zapowiedzią doskonałości osoby Chrystusa}

Analizując tekst Czwartej Księgi Machabejskiej, można zauważyć, że często jest podkreślana jedność braci na różnych płaszczyznach. Metaforycznie tę jedność wydaje się podkreślać obraz chóru, do którego zostało trzykrotnie przyrównane grono braci (zob. 4Mch 8,4; 13,8; 14,8). Chór w greckim teatrze jako składowa część dramatu pełnił znaczącą rolę, gdyż jego pieśni wypełniały przerwy pomiędzy aktami ${ }^{29}$. Składał się on

28 Zob. T. Brzegowy, Księgi historyczne Starego Testamentu, Academica 32, Tarnów 2008, 271. F. Gryglewicz (Księgi Machabejskie. Wstęp - przekład z oryginałukomentarz, Pismo Święte Starego Testamentu VI/4, Poznań 1961, 248), który podaje przedział czasowy 130-125 r. przed Chrystusem. Ł. Laskowski (Druga Księga Machabejska. Wstep, przekład z oryginatu, komentarz, Nowy Komentarz Biblijny. Stary Testament XIV/3, Częstochowa 2017, 92) natomiast, podając widełki czasowe dwóch wydarzeń (124 r. przed Chrystusem - redakcja jednego z listów umieszczonych na początku, oraz 63 r. przed Chrystusem - interwencja Pompejusza w Jerozolimie), stwierdza, że bliższe określenie czasu powstania Drugiej Księgi Machabejskiej jest trudne do sprecyzowania.

29 Zob. Mała Encyklopedia Kultury antycznej, red. Z. Piszczek, Warszawa 1988, 149. 
z określonej ilości osób, które tworząc zwartą grupę, wypowiadały się kolektywnie poprzez śpiew, któremu często towarzyszyły odpowiednie gesty czy też układy choreograficzne ${ }^{30}$. Działająca na wzór chóru siódemka braci niewątpliwie wyraża ich jedność.

Jedność braci podkreślona została również przez sposób ich wspólnego przemawiania: ,wszyscy razem jednym głosem to samo, jakby z jednej piersi rzekli"31 $(4 M c h 8,29)^{32}$. Na uwagę zasługują tutaj trzy elementy przytoczonego stwierdzenia. Po pierwsze, wzmianka, że przemawiali „,jednym głosem” (diá miás phōnés). Po drugie, że przemawiali „razem”. Autor Czwartej Księgi Machabejskiej użył w tym kontekście przysłówka homoú ('razem w tym samym miejscu, wespół, na raz, razem') ${ }^{33}$, który niewątpliwie podkreśla jedność działania. Po trzecie, w przytoczonej frazie pojawia się wymowne stwierdzenie, że młodzieńcy przemawiali ,z jednej (z tej samej) piersi" (apò tếs autếs psychếs). W tym kontekście pojawia się termin psyché, który między innymi posiada następujące znaczenia: 'dech, oddech, tchnienie, życie, dusza, osobowość, charakter, duch, serce, źródło życia, siła ożywcza'34. Egzegeci zauważają, że termin psyché w przywołanym stwierdzeniu może być - jak to ma miejsce zazwyczaj w LXX ${ }^{35}-$ odpowiednikiem hebr. ne $\bar{p} e \bar{s}^{36}$, który w podstawowym rozumieniu oznacza 'gardło' ${ }^{37}$. A zatem mowa braci była niejako przemawianiem wydobywającym się z jednego gardła. Ta metafora podkreśla nie tylko jednomyślnośćc ${ }^{38}$, ale także jedność $\mathrm{w}$ działaniu.

30 Szerzej na temat chóru w teatrze antycznej Grecji, zob. M. Kocur, Teatr antycznej Grecji, Dramat - Teatr 2, Wrocław 2001, 60-141.

31 Tłumaczenie polskie Czwartej Księgi Machabejskiej podawane jest w artykule za: Wojciechowski, Apokryfy, s. 123-200.

32 Autor Czwartej Księgi Machabejskiej najpierw podał hipotetyczną wspólną mowę młodzieńców (zob. 4Mch 8,17-26), którą mogliby wypowiedzieć, gdyby byli „lękliwego ducha" $(4 M c h 8,16)$, następnie zaś realną, którą mieli wygłosić jednogłośnie do Antiocha IV (zob. 4Mch 9,1-9).

33 O. Jurewicz, Słownik grecko-polski, Warszawa 2000-2001, t. 2, 108.

34 Jurewicz, Stownik grecko-polski, t. 2, s. 535.

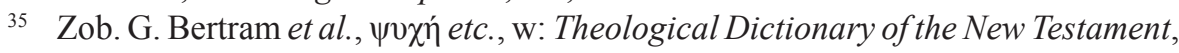
vol. 9, red. G. Friedrich, tł. G.W. Bromiley, Grand Rapids 1984, 617-618.

36 Zob. Wojciechowski, Apokryfy, s. 165.

37 L. Koehler - W. Baumgartner - J.J. Stamm, Wielki stownik hebrajsko-polski $i$ aramejsko-polski, t. 1, Prymasowska Seria Biblijna, red. wyd. pol. P. Dec, Warszawa 2008, 669.

38 Wojciechowski (Apokryfy, s. 165) w wyrażeniu ,wszyscy razem jednym głosem to samo, jakby z jednej piersi rzekli” dostrzega przejaw jednomyślności, która była postrzegana w starożytności jako cnota (zob. Aristoteles, Ethica Nicomachea, 1167b; Dio Chrysostomus, Oratio, 48). 
W 4Mch 13,13 również pojawia się podobny motyw wspólnego przemawiania ${ }^{39}$ zawarty w słowach: „Każdy z osobna i wszyscy razem, patrząc na siebie [...] mówili". Wyraża to fraza homoú pántes ('wszyscy razem'), w której użyty jest, jak w 4Mch 8,29, przysłówek homoú.

Jedność braci autor Czwartej Księgi Machabejskiej przedstawił także poprzez wyakcentowanie ich bratniej miłości (zob. 4Mch 13,19-26). W tym względzie nawiązał niewątpliwie do starożytnych autorów, którzy temu zagadnieniu poświęcali uwagę w swych rozważaniach ${ }^{40}$. Arystoteles podkreślał na przykład w tym kontekście, że „tożsamość ich [rodzeństwa] z rodzicami utożsamia ich wzajemnie między sobą (stąd mówi się o tej samej krwi, o wspólnym pniu itp.). Sa tedy bracia i siostry poniekąd tym samym w różnych indywiduach" 41 . Podobnie jak starożytni autorzy, tak i autor Czwartej Księgi Machabejskiejjako podstawę jedności i zgodnego działania braci wskazał na zrodzenie z tych samych rodziców, wspólne dorastanie, jednakowe kształcenie i wychowanie oraz codzienne przebywanie ze sobą (zob. 4Mch 13,19-22) ${ }^{42}$. W konsekwencji, jak zaznaczył autor Czwartej Księgi Machabejskiej, została pomiędzy braćmi zadzierzgnięta mocna więź braterskiej miłości: „Skoro tak oto ustala się wspólnie odczuwająca miłość braterska, siedmiu braci tym silniejsze wspólne odczucia miało ze sobą" (4Mch 13,23).

Konkluzją podkreślanej przez autora Czwartej Księgi Machabejskiej jedności siedmiu braci może być zawarte w apostroficznej pochwale młodzieńców sformułowanie „O święta i harmonijna zgodo siedmiu braci co do pobożności" (4Mch 14,3). Na uwagę zasługuje wyrażenie „harmonijna zgoda” (euármostos symphōnía). Przymiotnik euármostos przyjmuje między innymi następujące znaczenia: 'dobrze, świetnie zestawiony, uzgodniony, harmonijny"43, rzeczownik symphōnía natomiast - 'zgodność, współbrzmienie, akord, harmonia, zgoda, jednomyślność ${ }^{44}$. Zestawione razem oba terminy w $4 M c h$ 14,3 bardzo mocno pod-

39 Wspólna mowa zawarta jest w 4Mch 13,13-17.

40 Zob. np. Aristoteles, Ethica Nicomachea, 1161b-1162a; Xenophon, Cyropaedia, 8, 7, 14-16; Xenophon, Memorabilia, 2, 3, 4; Plutarchus, Moralia. De fraterno amore, 478a-492d. Por. Klauck, 4. Makkabäerbuch, s. 738.

${ }^{41}$ Aristoteles, Ethica Nicomachea, 1162a, tł. za: Arystoteles, Etyka Nikomachejska, tł. D. Gromska, Warszawa 2008, 254.

42 Szerzej na temat miłości braterskiej siedmiu braci męczenników, zob. H.J. Klauck, Brotherly Love in Plutarch and in 4 Maccabees, w: Greeks, Romans, and Christians. Essays in Honor of Abraham J. Malherbe, red. D.L. Balch - E. Ferguson W.A. Meeks, Minneapolis 1990, 144-156.

43 Jurewicz, Stownik grecko-polski, t. 1, s. 392.

44 Jurewicz, Stownik grecko-polski, t. 2, s. 341. 
kreślają jedność braci, której zwornikiem jest pobożność (eusebeia) rozumiana w Czwartej Księdze Machabejskiej jako całość religii żydowskiej ${ }^{45}$.

Podkreślana wielokrotnie jedność siedmiu braci pozwala postrzegać ich jak swego rodzaju ,jeden działający podmiot”. W tym kontekście łatwo odnieść „harmonijną jedność” siedmiu braci do jednej osoby Chrystusa i w konsekwencji dostrzegać w ich ściśle zespolonej zbiorowości Jego typ.

Mówiąc o siedmiu braciach jako doskonałej jedności, przede wszystkim uwagę czytelnika zwraca liczba tych braci wielokrotnie wspominana przez autora Czwartej Ksiegi Machabejskiej (zob. 4Mch 1,8; 8,3; 13,1.23; 14,3.4.7-8.12; 15,2.6.24.27; 16,1.3.6-7; 17,2.5.7.9.13; 18,6.20; por. 13,7). W tym kontekście można z kolei dostrzec odniesienie do symbolicznego znaczenia liczby synów, czyli do symboliki liczby siedem. Sam autor Czwartej Księgi Machabejskiej wydaje się zauważać takie znaczenie siódemki. Widać to wyraźnie w 4Mch 14,7-8: „O święta zgodna siódemko! Jako bowiem siedem dni stworzenia świata wokół pobożności, tak wokół siódemki w chórze krążąc, strach przed mękami unicestwili’" tutaj bezpośrednie nawiązanie do tradycji biblijnej, w której liczba siedem, jako liczba mająca szczególnie sakralny charakter, oznaczała „pełnię” $\mathrm{i}$,doskonałość"

Na uwagę $\mathrm{w}$ tym kontekście zasługuje także wzmianka zawarta w $4 M c h$ 16,13, gdzie mowa jest o „pełnej liczbie synów (ho tốn hyiốn arithmós)” zrodzonych przez matkę. We frazie tej pojawia się termin arithmós, który

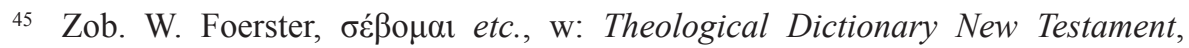
vol. 7, red. G. Kittel - G. Friedrich, tł. G.W. Bromiley, Grand Rapids 1983, 179. Por. Wojciechowski, Apokryfy, s. 166, 170; G. Scarpat, Quarto libro dei Maccabei. Testo, trduzione, introduzione e commento, Biblica Testi e Studi 9, nota storica G. Firpo, Brescia 2006, 76; U. Breitenstein, Beobachtungen zu Sprache, Stile und Gedankengut des Vierten Makkabäerbuchs, Basel - Stuttgart 1976, 169-170.

46 Zob. A. Dupont-Sommer, Le Quatrième livre des Machabées. Introduction, traduction et notes, Paris 1939, 146.

47 Zob. M. Lurker, Słownik obrazów i symboli biblijnych, tł. K. Romaniuk, Poznań 1989, 212-213; M.H. Pope, Seven, seventh, seventy, w: The Interpreter's Dictionary of the Bible. An Illustrated Encyclopedia, vol. 4, red. G.A. Buttrick et al., New York - Nashville 1962, 294-295; L. Ryken - J.C. Wilhoit - T. Longman III, Słownik symboliki biblijnej. Obrazy, symbole, motywy, metafory, figury stylistyczne $i$ gatunki literackie $w$ Piśmie Świętym, Prymasowska Seria Biblijna, tł. Z. Kościuk, Warszawa 1998, 904-905. Filon Aleksandryjski poświęcił wiele uwagi znaczeniu świętej liczby siedem w De opificio mundi (91-128). Zob. D.A. de Silva, 4 Maccabees. Introduction and Commentary on the Greek Text in Codex Sinaiticus, Septuagint Commentary Series, Leiden - Boston 2006, 215-216. 
oznacza między innymi 'liczbę'48, a także 'całkowitą sumę, ogół, całość'49. Można zatem przyjąć, że termin arithmós, w powiązaniu z liczbą siedem jako ilością zrodzonych synów, oznacza w tym miejscu pełną, doskonałą, całkowita liczbę, którą tworzyło siedmiu braci ${ }^{50}$.

Wyakcentowana bardzo mocno ,pełna”, „doskonała” liczba braci w typologicznej interpretacji może niewątpliwie wskazywać na pełnię i doskonałość Chrystusa. Ta doskonałość została w Nowym Testamencie wyrażona przede wszystkim poprzez wyakcentowanie jedności Chrystusa z Bogiem Ojcem (zob. J 10,30: „Ja i Ojciec jedno jesteśmy”; por. J 17,11.21-22), a co za tym idzie, Jego boskiego pochodzenia, czyli boską naturę (zob. Flp 2,6: „On, istniejac w postaci Bożej, nie skorzystał ze sposobności, aby na równi być z Bogiem"). Doskonałość Chrystusa wyraża się zatem w Jego boskiej naturze (zob. Kol 1,15: „On jest obrazem Boga niewidzialnego”; a także J 1,18: „Boga nikt nigdy nie widział, Ten Jednorodzony Bóg, który jest w łonie Ojca, [o Nim] pouczył”; Hbr 1,3: „Ten [Syn], który jest odblaskiem Jego chwały i odbiciem Jego istoty"). Apostoł Paweł nadto bardzo często pouczał o zamieszkującej w Chrystusie „Pełni bóstwa (tò plếrōma tếs theótētos)" (Kol 2,9; por. 1,19). Z tej pełni wszyscy wierzacy w Niego, zgodnie ze słowami Jana Apostoła, otrzymali łaskę: „Z Jego pełności (ek toú plērốmatos autoú) wszyscyśmy otrzymali - łaskę po łasce" $(\mathrm{J} 1,16)$, aby przez to stać się, jak pouczał Piotr Apostoł, ,uczestnikami boskiej natury” $(2 \mathrm{P} 1,4)^{51}$.

\section{Pochodzenie siedmiu braci od Abrahama typem pocho- dzenia Chrystusa}

Kilkukrotnie autor Czwartej Księgi Machabejskiej w korpusie księgi podkreślił pochodzenie siedmiu braci od Abrahama. Wyrażają to przede wszystkim następujące frazy: Abraam paídes (,dzieci Abrahama”-4Mch

48 Jurewicz, Stownik grecko-polski, t. 1, s. 109; H.G. Liddell - R. Scott - H.S. Jones, Greek-English Lexicon with a Revised Supplement, Oxford 1968, 240.

49 T. Muraoka, A Greek-English Lexicon of the Septuagint, Louvain - Paris Walpole 2009, 91.

50 Por. Anderson, 4 Maccabees, s. 561; de Silva, 4 Maccabees. Introduction and Commentary, s. 55.

51 Zarówno w tym miejscu, jak i w kolejnych przypadkach dobór tekstów biblijnych ma na celu nie tyle podanie wyczerpującej ilości odniesień, w których dostrzec można zrealizowanie się omawianego „typu”, lecz przytoczenie kilku najbardziej transparentnych przykładów, jakie samorzutnie się nasuwają. 
6,17.22), Abramiaiōn spermátōn apógona („Abrahamowego nasienia potomkowie" - 4Mch 18,1), hoi Abramiaioi paídes (,Abrahamowi chłopcy" - 4Mch 18,23), Abramiaios neanias („Abrahamowy młodzieniec”-4Mch 9,21). Należy przede wszystkim zaznaczyć, że tego rodzaju określenia (jak i pokrewne) miały na celu nie tyle opisać i wyjaśnić fizyczne pochodzenie siedmiu barci od konkretnego przodka, ale posiadały szersze zastosowanie, gdyż stanowiły uroczyste samookreślenie Żydów, dla których pochodzenie od Abrahama było powodem dumy, ponieważ wyrażało ich przynależność do narodu wybranego oraz uczestnictwo w obietnicach danych Abrahamowi ${ }^{52}$. Przykładem tego może być wyznanie Żydów zawarte w Ewangelii Janowej: „Jesteśmy potomstwem Abrahama” (J 8,33) oraz „Ojcem naszym jest Abraham” (J 8,39). W kontekście Czwartej Księgi Machabejskiej, jak zauważają egzegeci, może natomiast chodzić nie tyle o podkreślenie fizycznego pochodzenia siedmiu braci od Abrahama, ale raczej o wskazanie, że pochodzenie od Abrahama było dla nich obligacją religijną do przyjęcia postawy życiowej, jaką reprezentował ten patriarcha ${ }^{53}$, a ponadto stanowiło źródło odwagi do poniesienia śmierci męczeńskiej

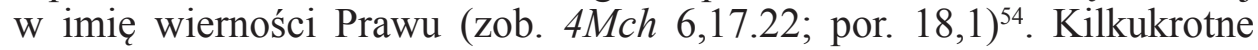
wzmianki o pochodzeniu siedmiu braci od Abrahama z pewnością miały także uświadomić czytelnikowi, że męczennicy rzeczywiście na wzór swego praojca w chwili próby przyjęli tę samą postawę posłuszeństwa i całkowitego poddania się woli Boga (zob. 4Mch 9,21; 14,20; 18,20; por. 18,23).

Pomijając jednak niuanse interpretacyjne kwestii pochodzenia siedmiu braci od Abrahama, można przyjąć, że wzmianka tego rodzaju może być postrzegana jako typ, czyli zapowiedź pochodzenia również samego Chrystusa od Abrahama. Podkreślają to umieszczone w Ewangeliach rodowody (zob. Mt 1,1-17; Łk 3,23-38), w których Abraham jest wymieniamy jako jedno z ogniw w łańcuchu kolejnych przodków Jezusa (zob. Mt 1,1.17; Łk 3,34). Warto wspomnieć, że w Ewangelii Mateusza to właśnie od Abrahama rozpoczyna się prezentowana genealogia Chrystusa (zob. Mt 1,2). W ten sposób autor Ewangelii podkreślił fakt, że Jezus jako potomek Abrahama jest członkiem narodu izraelskiego, czyli po prostu Izraelitą ${ }^{55}$.

52 Zob. Wojciechowski, Apokryfy, s. 155-156. Por. J. Jeremias, A $\beta \rho \alpha \alpha ́ \mu, w:$ Theological Dictionary of the New Testament, vol. 1, red. G. Kittel, t1. G.W. Bromiley, Grand Rapids 1983, 8; Dupont-Sommer, Le Quatrième livre des Machabées, s. 111.

53 Zob. Scarpat, Quarto libro dei Maccabei,s. 221.

54 Zob. de Silva, 4 Maccabees. Introduction and Commentary, s. 146.

55 Zob. U. Luz - H.Koester, Matthew 1-7. A Commentary on Matthew 1-7, Hermeneia - a Critical and Historical Commentary on the Bible, Minneapolis 2007, 8283. Por. A. Paciorek, Ewangelia wedtug świętego Mateusza. Cześć 1. Rozdziały 1-13, Nowy Komentarz Biblijny. Nowy Testament I/1, Częstochowa 2005, 74. 
A zatem siedmiu braci jako potomkowie Abrahama mogą stanowić typ Chrystusa również pochodzącego od Abrahama.

\section{Kierowanie się przez braci „pobożnym rozumem” typem poddania się Chrystusa woli Ojca}

Tematyka „pobożnego rozumu (eusebés logismós)” to zasadnicza kwestia poruszana w Czwartej Księdze Machabejskiej. Już w pierwszym wersecie na ten temat jest postawiona teza (4Mch 1,1: „Wysoce filozoficzną podjąć mam kwestię, czy pobożny rozum samowładnie panuje nad namiętnościami”), której prawdziwość autor Czwartej Księgi Machabejskiej wykazuje w całym swym dziele. Próba dookreślenia, czym jest „pobożny rozum”, znajduje się w 4Mch 1,15-17: „Rozum zatem to umysł na słusznej zasadzie wybierający życie mądrości. Mądrość to znajomość boskich i ludzkich spraw oraz ich przyczyn. Ta jest wychowaniem przez prawo [...]".

A zatem pobożny rozum to ten, który kieruje się mądrością ukształtowaną przez Prawo ${ }^{56}$. W korpusie swego dzieła autor Czwartej Księgi Machabejskiej podkreślił parokrotnie, że siedmiu braci było wychowywanych w oparciu o nakazy Prawa (zob. 4Mch 13,22-24; 18,10). Dzięki temu zdobyli „,pobożny rozum”, który pozwolił im wytrwać w chwilach próby, kiedy to w imię wierności Prawu musieli znieść okrutne tortury oraz ponieść męczeńską śmierć. „Pobożny rozum”, innymi słowy mówiąc, dał im możliwość zapanowania nad wszelkimi namiętnościami (strachem, bólem), a także nad zwodniczymi przyjemnościami, które w zamian za niewierność wobec Prawa obiecywał Antioch IV (zob. 4Mch 8,5-8; 12,5).

Dzięki ,pobożnemu rozumowi” siedmiu braci wykazało się posłuszeństwem wobec nakazów Prawa, czyli, innymi słowy, okazali się posłuszni woli Bożej zawartej w nakazach Prawa. W ten sposób mogą stanowić typ Chrystusa poddanego woli Boga Ojca. O tym pouczył autor Czwartej Ewangelii, przytaczając słowa Chrystusa: „Moim pokarmem jest wypełnić wolę Tego, który Mnie posłał, i wykonać Jego dzieło” (J 4,34); ,[...] z nieba zstapiłem nie po to, aby pełnić swoją wolę, ale wolę Tego, który Mnie posłał" (J 6,38). Gotowość do wypełnienia woli Boga Ojca Jezus wyraził transparentnie w czasie modlitwy w Ogrodzie Getsemani: „Ojcze mój, jeśli

56 Zob. Wojciechowski, Apokryfy, s. 129. Por. R. Weber, Eusebeia und Logismos. Zum philosophischen Hintergrund von 4 Makkabäer, „Journal for the Study of Judaism” 22 (1991) f. 2, 212-234. 
to możliwe, niech Mnie ominie ten kielich! Wszakże nie jak Ja chcę, ale jak Ty. [...] Ojcze mój, jeśli nie może ominąć Mnie ten kielich, i muszę go wypić, niech się stanie wola Twoja!" (Mt 26,39.42; por. Mk 14,36; Łk $22,42)$. A zatem siedmiu braci poddanych nakazom Prawa pochodzącego od Boga ${ }^{57}$ jest typem Chrystusa posłusznego woli Ojca.

Ponadto owych siedmiu braci kierujących się ,,pobożnym rozumem”, a przez to poddanych Prawu, może stanowić typ Chrystusa w bardziej literalny sposób. Ich poddanie się nakazom Prawa może być prefiguracją poddania się Chrystusa poszczególnym nakazom Prawa, czego przykładem w przypadku Chrystusa może być między innymi poddanie się obrzezaniu i ofiarowaniu Bogu w Świątyni Jerozolimskiej (zob. Łk 2,21-24), po uzdrowieniu trędowatych nakazanie im, aby pokazali się kapłanom i złożyli ofiarę przepisaną przez Mojżesza (zob. Mt 8,4), wypełnianie praktyk religijnych i obchodów świątecznych zgodnie znakazami Prawa (zob. Mt 26,17; Mk 14,12; Łk 2,41-42; 22,7-8; J 2,13; 5,1).

\section{Namowy Antiocha IV typem kuszenia Chrystusa przez diabła}

Antioch IV, chcąc nakłonić siedmiu braci do złamania nakazów Prawa, zanim zdecydował się zastosować wobec nich tortury, pierwszorzędnie rozpoczął od perswazji. W tym kontekście pojawiają się obok gróźb nawet kuszące obietnice króla:

[...] lecz również napominam, by ustąpiwszy mi cieszyć się moją przyjaźnią. Potrafiłbym, jak karzę nieposłusznych moim rozkazom, być tak samo dobroczyńcą dla posłusznych mi. Zaufajcie więc, a stanowiska zwierzchnie w moich dziedzinach otrzymacie, wyparłszy się ojczystego obyczaju waszego obywatelstwa. A przejąwszy helleński sposób życia, zmieńcie jego tryb i rozkoszujcie się waszą młodością (4Mch 8,5-8).

W przytoczonych słowach pojawia się obietnica kariery na dworze Seleucydy. Wyrazem tego miało być obdarzenie każdego z siedmiu braci honorowym tytułem „królewskiego przyjaciela (phílos basiléōs)”. Obdarzeni tym tytułem stawali się dworzanami króla lub też posiadali za-

57 To pochodzenie Prawa od Boga wyrażają dookreślenia, które odnoszą się do terminu nómos: nómos theíos (4Mch 5,16;9,15;11,27), nómos theoú (4Mch 13,22). Przekazanie Prawa człowiekowi przez Boga wzmiankowane jest wprost w 4Mch 3,23. 
szczyt bliskiego z nim kontaktu. Tworzyli oni niekiedy przyboczną radę królewską, byli również wykonawcami najważniejszych rozkazów króla, a także zarządcami prowincji lub dowódcami armii ${ }^{58}$. Posiadali przywilej noszenia purpurowych szat oraz purpurowego kapelusza z szerokim rondem $^{59}$. Każdy z siedmiu braci obdarzony tytułem „królewskiego przyjaciela" miał w konsekwencji zostać także zwierzchnikiem jakiejś części imperium seleucydzkiego (zob. 4Mch 8,7). Tę obietnicę Antioch IV powtórzył raz jeszcze $\mathrm{w}$ indywidualny sposób do siódmego $\mathrm{z}$ braci, aby nakłonić go do złamania Prawa (zob. 4Mch 12,5). Ponadto w przypadku ostatniego $\mathrm{z}$ braci Seleucyda próbował wykorzystać matkę młodzieńców, aby widok jej cierpienia obudził litość u dziecka. Wywołanie litości nad matką, w zamierzeniu Antiocha IV, miało stać się czynnikiem pobudzającym ostatniego z synów do ocalenia własnego życia za cenę przekroczenia Prawa, aby w konsekwencji matka mogła cieszyć się posiadaniem choćby jednego dziecka (zob. 4Mch 12,6).

W swych namowach Antioch IV przekonywał nadto siedmiu braci, że złamanie nakazu Prawa pod przymusem czy też pod wpływem strachu nie posiada negatywnej klasyfikacji moralnej, stąd też nie powinni obawiać się karania ze strony Bożej sprawiedliwości (zob. 4Mch 8,14).

We wspólnej mowie siedmiu braci (zob. 4Mch 9,1-9) pojawia się jednak negatywna ocena perswazji Antiocha IV oraz jego zwodniczych obietnic: „Tyranie, doradco do przekraczania prawa, nienawidząc nas nie lituj się nad nami bardziej niż my sami. Za dotkliwszą bowiem od samej śmierci uważamy twoją litość z ratunkiem [...]" (4Mch 9,3-4). W tym kontekście Antioch IV jawi się jako zwodniczy kusiciel, który obietnicą doczesnych korzyści, będących pozornym jedynie dobrem, chciał doprowadzić młodzieńców do złamania Prawa. Jego wrogą postawę wobec młodzieńców i wysiłki złamania ich woli autor Czwartej Księgi Machabejskiej opisał za pomocą metafory agonistycznej: „Zaprawdę były to bowiem boskie zawody, w których wystąpili. [...] Bracia zaś współzawodnikami. Tyran był przeciwnikiem; świat i ludzkość widzami” (4Mch 17,11.13-14).

W przytoczonym stwierdzeniu Antioch IV ukazany został jako przeciwnik walczący z wiernymi Prawu młodzieńcami; celem tej walki było zmuszenie ich do złamania nakazów Prawa. Podjęta przez Antiocha IV wroga działalność wobec narodu żydowskiego, której przejawem było prześladowanie Żydów za wierność Prawu oraz zbezczeszczenie świątyni, sprawiła, że Seleucyda był postrzegany jako jeden z największych wrogów narodu żydowskiego w historii. Jego obraz z Drugiej Księgi Machabejskiej

58 Zob. Wojciechowski, Apokryfy, s. 59; Gryglewicz, Księgi Machabejskie, s. 65.

59 Zob. J.A. Goldstein, I Maccabees. A New Translation with Introduction and Commentary, The Anchor Bible 41, Garden City - New York 1976, 232. 
(zob. 2Mch 9,12) oraz z Księgi Daniela (zob. Dn 11,36-37), gdzie jest ukazany jako ten, który pragnął niejako zająć miejsce Boga, wykreował $\mathrm{z}$ niego jednego $\mathrm{z}$ większych bezbożników ${ }^{60}$. Stąd też w tradycji Ojców Kościoła Antioch IV był postrzegany jako typ antychrysta ${ }^{61}$.

Mając na uwadze powyższy obraz Antiocha IV oraz jego namowy siedmiu braci do złamania nakazów Prawa, można dostrzec w jego postawie typ szatana kuszącego Jezusa na pustyni (zob. Mt 4,1-11; Mk 1,12-13; Łk 4,1-13). Kusząc Chrystusa, szatan między innymi zaproponował ofiarowanie $\mathrm{Mu}$ „wszystkich królestw świata oraz ich przepychu” (Mt 4,9). W zamian za to zażądał oddanie sobie pokłonu. Odrzucając tę propozycję, Jezus przypomniał szatanowi jeden z nakazów zawartych w Prawie: „Panu, Bogu swemu, będziesz oddawał pokłon i Jemu samemu służyć będziesz" (Mt 4,10; por. Pwt 6,13). A zatem i tym razem w osobach siedmiu braci odrzucających zwodnicze namowy Antiocha IV można dostrzec typ Chrystusa odrzucającego pokusy szatana.

\section{Męczeńska ofiara braci typem ofiary zbawczej Chrystusa}

Analizując relację dotyczącą tortur oraz męczeńskiej śmierci siedmiu braci, można dostrzec, że zarówno opis zadawanej kaźni oraz śmierci, a także refleksje teologiczne autora Czwartej Księgi Machabejskiej na temat znaczenia śmierci męczenników dostarczają argumentacji, aby męczeńską śmierć siedmiu braci postrzegać jako typ zbawczej ofiary Chrystusa.

\subsection{Tortury zadane braciom typem męki Chrystusa}

Opis tortur oraz męczeńskiej śmierci w Czwartej Księdze Machabejskiej został przedstawiony bardzo realistycznie - można by powiedzieć, że wręcz drastycznie. Tego rodzaju ujęcie jest wyrazem założeń greckiej retoryki, zwłaszcza stylu azjańskiego ${ }^{62}$. Dopatrując się typu męki i śmierci Chrystusa w opisie tortur i męczeńskiej śmierci siedmiu braci, przede wszystkim należałoby zwrócić uwagę na trzy elementy. Po pierwsze,

60 Zob. szerzej: Baran, Życie i śmierć Antiocha IV, s. 115-118, 130-132.

61 Zob. Hieronymus, Commentariorum in Danielem Prophetam, 11, 21 [712]; 11, 31 [716]. Por. B. Rigaux - P. Grelot, Antychryst, w: Słownik teologii biblijnej, red. X. Léon-Dufour, tł. K. Romaniuk, Poznań 1994, 52; Baran, Życie i śmierć Antiocha $I V$, s. 103.

62 Zob. Wojciechowski, Apokryfy, s. 100. 
w opisie męczeństwa pierwszego z braci znajduje się wzmianka na temat odarcia z szat młodzieńca oraz biczowania: ,[...] zerwawszy tunikę związali jego ręce i ramiona rzemieniami po obu stronach. Gdy zaś uderzając go biczami zmęczyli się [...], cisnęli go na koło" (4Mch 9,11-12).

W opisie tym można dostrzec paralele z opisem biczowania Chrystusa i odarcia Go z szat przez żołnierzy (zob. Mt 27,26-27; Mk 15,15; J 19,1). Ten rodzaj tortur pierwszego z braci może być zatem postrzegany jako typ biczowania i odarcia z szat Chrystusa. Z przekazu Ewangelii wiadomo również, że jako szatę Chrystus nosił, podobnie jak wspomniany pierwszy z braci, tunikę. Wzmianka na ten temat znajduje się w J 19,23 oraz 4Mch 9,11, gdzie za każdym razem pojawia się ten sam termin ho chitốn ('chiton' - lniana szata wkładana wprost na ciało)"'63, czyli po prostu 'tunika' ${ }^{64}$.

Po drugie, ciekawą informację podał autor Czwartej Księgi Machabejskiej na temat tortur szóstego brata: „Ostre rozżarzone rożny do pleców mu przykładali, a przebiwszy boki (tà pleurá) wypalali wnętrzności" $(4 M c h 11,19)$. Tego rodzaju wzmianka może być potraktowana jako typ przebicia boku Chrystusa wiszącego na krzyżu: ,jeden z żołnierzy włócznią przebił Mu bok (hē pleurá)" (J 19,34). A zatem wzmianka o przebitych bokach szóstego z braci współbrzmi niejako z zapowiedzią proroka Zachariasza: „Będą patrzeć na Tego, którego przebili” (Za 12,10), którą przytacza sam autor Czwartej Ewangelii (J 19,37).

Po trzecie, należy zauważyć, że poszczególni bracia, po wstępnych torturach w niektórych przypadkach, byli następnie rozciągani (przywiązywani) na jakimś narzędziu mąk, na którym ponosili śmierć męczeńską ${ }^{65}$. W opisach męczeńskiej śmierci młodzieńców autor Czwartej Księgi Machabejskiej wymienił różne rodzaje tych narzędzi: „koło” (zob. 4Mch 9,12), „machina i napinacz”(zob. 4Mch 9,26), „machiny” (zob. 4Mch 10,5), „,napinacz” (4Mch 11,9). Każde z tych narzędzi tortur, będące ostatecznie narzędziem śmierci, może być postrzegane jako typ krzyża, na którym został „rozciągnięty”, to znaczy ukrzyżowany Chrystus (zob. Mt 27,35; Mk 15,24; Łk 23,33; J 19,18). Jak w przypadku braci męczenników, tak i w przypadku Chrystusa narzędzie kaźni stało się także narzędziem śmierci. A zatem rozpinanie braci męczenników na różnych narzędziach tortur może niewątpliwie stanowić typ ukrzyżowania Chrystusa.

63 Jurewicz, Stownik grecko-polski, t. 2 s. 514.

64 Muraoka, A Greek-English Lexicon, s. 733.

65 Brakuje wzmianki o takim narzędziu w przypadku brata czwartego (zob. 4Mch 10,12-11,1) oraz siódmego, o którym autor Czwartej Księgi Machabejskiej napisał, że sam rzucił się na patelnię jako narzędzie kaźni, na której „oddał ducha” (4Mch 12,19). 


\subsection{Ofiara „zastępcza” braci typem ofiary przebłagalnej Chrystusa}

$\mathrm{Na}$ szczególną uwagę zasługuje interpretacja teologiczna śmierci męczenników, jaką podał autor Czwartej Księgi Machabejskiej. Jest ona zawarta w kilku miejscach i dotyczy zarówno siedmiu braci, jak również ich matki oraz starca Eleazara. Po raz pierwszy pojawia się w $4 M c h 1,11$ : ,[męczennicy] przyczynili się do upadku gnębiącej naród tyranii, zwyciężając tyrana wytrwałością, tak że oczyszczona została przez nich ojczyzna". W świetle przytoczonego tekstu ofiara męczenników miała wartość oczyszczającą dla całej ojczyzny. Komplementarnie z tym tekstem brzmi werset 4Mch 6,29, gdzie znajduje się modlitwa Eleazara: „Uczyń mą krew ich oczyszczeniem i jako okup za ich życie zabierz życie moje (antipsychon autốn labè tèn emèn psychến)".

Niewątpliwie chodzi tutaj o oczyszczenie z grzechów (por. 4Mch 17,21), których - w kontekście czasów machabejskich - dopuściła się część społeczności żydowskiej poprzez ulegnięcie i praktykowanie poganskich (greckich) obyczajów, które naruszały nakazy Prawa ${ }^{66}$ (zob. $4 M c h$ 4,16-20; por. 1Mch 1,10-15.43.52-53; 2,23; 2Mch 7,17). Idea oczyszczenia łączy się tutaj ściśle z ideą ofiary zastępczej, która miała charakter ofiary przebłagalnej, co zostało wyrażone w $4 M c h$ 17,20-22 ${ }^{67}$ :

[...] dzięki nim [...] tyran został ukarany i ojczyzna oczyszczona, jakby stali się okupem za życie wobec grzechów narodu (hốsper antípsychon gegonótas tếs toú éthnous hamartias). A przez krew pobożnych owych i ofiarę przebłagalną ich śmierci (dià toú haimatos tốn eusebốn ekeinōn kaì toú hilastêriou toú thanátou autốn) boska opatrzność poniżony Izrael wyratowała.

Dzięki męczeńskiej śmierci, która miała wymiar ekspiacji zastępczej ${ }^{68}$, dokonało się oczyszczenie z grzechów narodu żydowskiego oraz, w konsekwencji ${ }^{69}$, uwolnienie go przez Boga z opresji Antiocha IV, co sprawiło,

66 Por. Wojciechowski, Apokryfy, s. 128.

67 Por. J.W. van Henten, The Maccabean Martyrs as Saviours of the Jewish People. A Study of 2 and 4 Maccabees, Supplements to the Journal for the Study of Judaism 57, Leiden 1997, 150; M. Hadas, The Third and Fourth Books of Maccabees, Jewish Apocryphal Literature 2, New York 1953, 121.

68 Zob. Hadas, The Third and Fourth Books of Maccabees, s. 181.

69 W świetle Drugiej Księgi Machabejskiej kara, jaka spadła na społeczność żydowską, była wynikiem grzechów odstępstwa od Prawa przez cześć tejże społeczności. Grzechy nardu żydowskiego spowodowały, że ,wielki gniew [Boży] strasznie zaciążył nad Izraelem" (1Mch 1,64). Wyrazem gniewu Bożego było karanie narodu żydowskiego przejawiające się w prześladowaniach za czasów Antiocha IV. Powrót do wierności Prawu 
że naród odzyskał uprzedni stan spokoju (zob. $4 M c h 18,4)^{70}$. W tym kontekście zostały wyeksponowane dwa elementy. Pierwszy z nich to krew męczenników, drugi to ich śmierć jako zastępcza ofiara przebłagalna. Idea „zastępczości” została wyrażona poprzez przymiotnik antípsychos (4Mch $6,29 ; 17,21)$, który można tłumaczyć za pomocą takich zwrotów, jak: 'dany ze względu na"71, "w zastępstwie'72, 'dany za życie, dający własne życie jako rekompensatę za życie kogoś innego' ${ }^{73}$. Należy zaznaczyć, że w tradycji starotestamentalnej krew czy też zastępcze ofiary ze zwierząt stanowiły powszechny elementy w rytach przebłagalnych (zob. np. Kpł 17,11; 16,722; Pwt 21,1-9; Ez 43,20)74.

W Starym Testamencie podobne idee pojawiają się $\mathrm{w}$ tak zwanej Czwartej Pieśni Sługi Pańskiego (Iz 52,13-53,12), której bohater postrzegany był już przez hagiografów Nowego Testamentu jako zapowiedź Mesjasza, czyli Chrystusa ${ }^{75}$. Na szczególną uwagę zasługują wersety Iz 53,5.10-11, w których występuje wprost idea zastępczej ofiary z życia za grzechy ludu ${ }^{76}$. W tym kontekście łatwo dostrzec zbieżność w interpretacji męczeńskiej śmierci siedmiu braci oraz zbawczej ofiary Chrystusa. Ta zbieżność jest wyraźnie widoczna w kilku tekstach Nowego Testamentu, które zawierają ideę oczyszczenia z grzechów przez krew Chrystusa oraz

natomiast sprawił, że gniew Boży zamienił się w litość Bożą i wówczas Bóg uwolnił swój lud od okrutnych prześladowań. Zob. szerzej np. G.M. Baran, Karanie narodu żydowskiego przez Boga jako wymiar Bożej $\pi \alpha 1 \delta \varepsilon i ́ \alpha$ według Drugiej Księgi Machabejskiej, SSHT 49 (2016) z. 2, 408-429. Grzechy ludu w konsekwencji były zatem przyczyną karania, oczyszczenie z nich dawało możliwość uwolnienia od kary, czyli wyzwolenie z ucisku prześladowców.

70 Por. van Henten, The Maccabean Martyrs, s. 153.

71 Muraoka, A Greek-English Lexicon, s. 60.

72 Zob. Scarpat, Quarto libro dei Maccabei, s. 227-228.

73 Liddell - Scott - Jonnes, Greek-English Lexicon, s. 166.

74 Zob. de Silva, 4 Maccabees. Introductio and Commentary, s. 147; Hadas, The Third and Fourth Books of Maccabees, s. 121; A.P. O'Hagan, The Martyr in the Fourth Book of Maccabees, „Liber Annuus. Studium Biblicum Franciscanum” 24 (1974) 117 118. Nota bene de Silva (4 Maccabees. Introductio and Commentary, s. 249-251) zauważa, że autor Czwartej Księgi Machabejskiej, przedstawiając znaczenie męczeńskiej śmierci męczenników machabejskich, najwyraźniej posłużył się kultowym językiem rytuału Dnia Przebłagania.

75 Zob. np. L. Stachowiak, Księga Izajasza II-III. 40-66. Wstęp - przekład z oryginatu - komentarz - ekskursy, Pismo Święte Starego Testamentu IX/2, Poznań 1996, 217, 351-352: J. Homerski, Cierpiacy wybawca i orędownik (Analiza egzegetyczno-teologiczna perykopy Iz 52,13-53,12), RTK 24 (1977) z. 4, 89-90; J. Homerski, Cierpiacy Mesjasz w starotestamentalnych przepowiedniach prorockich, RTK 27 (1980) z. 1, 39-41.

76 Zob. Dupont-Sommer, Le Quatrième Livre des Machabées, s. 42. 
ideę zastępczej Jego ofiary za grzechy ludu. Na ogół egzegeci przytaczają następujące teksty ${ }^{77}$ : Mk 10,45 (por. Mt 20,28, „Bo i Syn Człowieczy nie przyszedł, aby Mu służono, lecz żeby służyć i dać swoje życie na okup za wielu [doúnai tèn psychèn autoú lýtron antì pollṓ]"), 1Tm 2,6 (,[Chrystus Jezus] wydał siebie samego na okup za wszystkich jako świadectwo we właściwym czasie”), Hbr 9,12 (,[Chrystus] ani nie przez krew kozłów i cielców, lecz przez własną krew wszedł raz na zawsze do Miejsca Świętego, zdobywszy wieczne odkupienie").

A zatem podobnie jak ofiarowane życie (czyli śmierć męczeńska) siedmiu braci stało się okupem za życie ludu splamionego grzechem, tak również ofiara z życia Chrystusa stała się „okupem za wielu”, okupem, którego celem było uwolnienie od grzechów (zob. np. 1Kor 15,3: „Przekazałem wam na początku to, co przejąłem: że Chrystus umarł - zgodnie z Pismem za nasze grzechy”; 1P 2,24: „On sam, w swoim ciele poniósł nasze grzechy na drzewo, abyśmy przestali być uczestnikami grzechów, a żyli dla sprawiedliwości - Krwią Jego ran zostaliście uzdrowieni”; 1P 3,18: „Chrystus bowiem również raz umarł za grzechy, sprawiedliwy za niesprawiedliwych, aby was do Boga przyprowadzić”; 1J 1,7: ,[...] krew Jezusa, Syna Jego, oczyszcza nas z wszelkiego grzechu”; 1J 4,10: „W tym przejawia się miłość, że nie my umiłowaliśmy Boga, ale że On sam nas umiłował i posłał Syna swojego jako ofiarę przebłagalną za nasze grzechy”; Hbr 9,14: „,...] o ile bardziej krew Chrystusa, który przez Ducha wiecznego złożył Bogu samego siebie jako nieskalaną ofiarę, oczyści wasze sumienia z martwych uczynków, abyście służyć mogli Bogu żywemu”). W tym kontekście należy także zauważyć, że zarówno w przypadku siedmiu braci, jak również Chrystusa pojawia się motyw krwi.

W teologicznej refleksji autora Czwartej Księgi Machabejskiej na temat śmierci męczeńskiej siedmiu braci pojawia się jeszcze jeden element, który pozwala dostrzec paralele z ofiarą Chrystusa. Jest nim termin hilastếrion, który może oznaczać zarówno 'miejsce, w którym są sprawowane rytuały dla przebłagania bóstwa', jak również 'ofiarę przebłagalną' ${ }^{78}$. Termin hilastếrion w 4Mch 17,22 jest określeniem śmierci męczenników, która

77 Zob. Wojciechowski, Apokryfy, s. 157; Dupont-Sommer, Le Quatrième Livre des Machabées, s. 42.

78 Muraoka, A Greek-English Lexicon, s. 340. Por. Scarpat, Quarto libro dei Maccabei, s. 405. Należy zaznaczyć, że w LXX termin hilastérion oznacza tak zwaną ,przebłagalnię”, która stanowiła pokrywę Arki Przymierza. Hebr. odpowiednik tego terminu brzmi kap̄ōret (zob. np. Wj 25,18; 38,7; Kpł 16,2) i znaczy 'pojednanie', a etymologicznie pochodzi od czasownika w koniugacji piel kip̄er ('przebłagać, wynagrodzić, dokonać przebłagania'). Zob.Koehler - Baumgarnter - Stamm, Wielki słownik hebrajsko-polski, t. 1, s. 465, 467. Por. G.A.F. Knight, Arka, tł. J. Marzęcki, 
została w ten sposób zinterpretowana jako „ofiara przebłagalna”. Również Chrystus został określony tym samym terminem w Rz 3,25: „Jego to ustanowił Bóg narzędziem przebłagania przez wiarę mocą Jego krwi (hòn proétheto ho theòs hilastếrion, dià tếs písteōs, en tồ(i) autoú haímati)".

Ujmując typologicznie męczeńską śmierć braci męczenników, należy uwzględnić jeszcze jedną kwestię, a mianowicie dobrowolność i pełną gotowość na tego rodzaju śmierć. W punkcie drugim niniejszej pracy była mowa o „pobożnym rozumie”, dzięki któremu każdy z braci potrafił zachować w trudnych okolicznościach wierność Prawu, a przez to poddać się woli Boga. W punkcie trzecim zaś została przedstawiona kwestia odrzucenia przez poszczególnych braci kuszących perswazji Antiocha IV. To wszystko wskazuje, że bracia w wolny sposób obrali drogę prowadzącą do męczeńskiej śmierci za wierność Prawu, co w konsekwencji przyjęło wymiar ofiary przebłagalnej za naród. Potwierdzeniem tej tezy może być stwierdzenie zawarte w 4Mch 14,4: ,Żaden z siedmiu młodzieniaszków nie stchórzył ani wobec śmierci się nie zawahał". Taka postawa wobec tortur oraz śmierci męczeńskiej może być również postrzegana jako typ postawy Chrystusa, który dobrowolnie złożył ofiarę z samego siebie Bogu Ojcu (zob. np. J 10,15.18: „Życie moje oddaję za owce. [...] Nikt Mi go nie zabiera, lecz Ja od siebie je oddaję. Mam moc je oddać i mam moc je znów odzyskać”; Ga 1,4: ,[Jezus Chrystus] wydał samego siebie za nasze grzechy [...]”; Ef 5,2: „Chrystus was umiłował i samego siebie wydał za nas w ofierze i dani na wdzięczną wonność Bogu [...]”; por. Ga 2,20; Ef $5,25 ; 1 \mathrm{Tm} 2,6 ; \mathrm{Tt} 2,14)$.

Jak wynika z przedstawionych analiz, śmierć siedmiu braci może być postrzegana jako typ zbawczej ofiary Chrystusa. Uwidacznia się to zarówno na płaszczyźnie narracji, użytego słownictwa, jak również teologicznej interpretacji.

\section{6. „Utwierdzenie w niebie” braci typem wniebowstąpienia Chrystusa}

Patrząc na siedmiu braci w perspektywie wieczności, można również postrzegać ich jako typ Chrystusa. Wniosek taki rodzi się na kanwie słów pochwały matki siedmiu młodzieńców, w której to pochwale autor Czwartej Księgi Machabejskiej zawarł między innymi następujące stwier-

w: Słownik wiedzy biblijnej, Seria biblijna „Vocatio”, red. B.M. Metzger - M.D. Coogan, Warszawa 1996, 41. 
dzenie: „Księżyc na niebie z gwiazdami tak dostojnie nie spoczywa, jak ty, gwiazdom równych siedmiu chłopców światłem prowadząca ku pobożności, we czci u Boga spoczęłaś i utwierdziłaś się z nimi w niebie" (4Mch 17,5).

Chociaż pierwszorzędnie mówi się tutaj o matce siedmiu braci, to jednak również i o ich losie pośmiertnym jest mowa w tym kontekście: zostali utwierdzeni w niebie u Boga. W 4Mch 18,23 znajduje się nadto wzmianka, że młodzieńcy po męczeńskiej śmierci „w gromadę $\mathrm{z}$ ojców chórem są złączeni”. Jak widać z przytoczonych tekstów, siedmiu braci jako rekompensatę za doznane cierpienia i okazaną w nich wytrwałość otrzymali nagrodę (zob. 4Mch 9,8), której istotą jest wieczne przebywanie z Bogiem. To „utwierdzenie w niebie u Boga" siedmiu braci może stanowić typ wniebowstąpienia Chrystusa i zajęcia przez Niego miejsca po prawicy Ojca (zob. np. Mk 16,19: „Po rozmowie z nimi Pan Jezus został wzięty do nieba i zasiadł po prawicy Boga"; Łk 24,51: „A kiedy ich błogosławił, rozstał się z nimi i został uniesiony do nieba”; Rz 8,34: „Chrystus Jezus, który poniósł [za nas] śmierć, co więcej - zmartwychwstał, siedzi po prawicy Boga"; Ef 1,20: ,[Bóg] wskrzesił Go z martwych i posadził po swojej prawicy na wyżynach niebieskich”; Hbr 1,3: ,[...] dokonawszy oczyszczenia z grzechów, zasiadł po prawicy Majestatu na wysokościach"; por. Dz 1,9-11; 7,55-56; Kol 3,1; Hbr 8,1; 10,12; 12,2; 1P 3,22).

\section{Podsumowanie}

Jak zostało zapowiedziane już na wstępie, w niniejszym artykule została przedstawiona swego rodzaju próba zastosowania egzegezy typologicznej do tekstu Czwartej Księgi Machabejskiej. W świetle przeprowadzonych analiz widać wyraźnie, że siedmiu braci męczenników może być postrzeganych jako typ Chrystusa. Liczba siedem, określająca ich ilość, jest typem doskonałości osoby Chrystusa; pochodzenie siedmiu braci od Abrahama - typem pochodzenia Chrystusa; kierowanie się przez braci „,pobożnym rozumem” - typem poddania się woli Ojca przez Chrystusa; namowy Antiocha IV - typem kuszenia Chrystusa przez diabła; męczeńska ofiara braci - typem ofiary zbawczej Chrystusa; "utwierdzenie w niebie” braci - typem wniebowstąpienia Chrystusa. Posługując się cytowanym wyżej stwierdzeniem św. Ireneusza, można powiedzieć, że rzeczywiście w Czwartej Księdze Machabejskiej ukryty jest Chrystus za pomocą typów, które związane są z postaciami siedmiu braci machabejskich. Mając natomiast na uwadze fakt, że Czwarta Księga Machabejska czerpała z Drugiej 
Księgi Machabejskiej lub z tych samych źródeł, można stwierdzić, iż sposób przedstawienia przez autora z I wieku po Chrystusie siedmiu braci, których historia rozegrała się w II wieku przed Chrystusem, jeszcze bardziej - w perspektywie typologicznej - przybliżył ich do osoby Chrystusa. W tym kontekście na uwagę zasługuje także matka siedmiu braci, której osobę można byłoby zinterpretować jako typ Maryi - Matki Chrystusa.

\section{Siedmiu braci machabejskich z Czwartej Księgi Machabejskiej jako typ Chrystusa. Próba zastosowania egzegezy typologicznej do tekstu Czwartej Księgi Machabejskiej}

(streszczenie)

Jak zostało zapowiedziane już na wstępie, w niniejszym artykule została przedstawiona swego rodzaju próba zastosowania egzegezy typologicznej do tekstu Czwartej Księgi Machabejskiej. W świetle przeprowadzonych analiz widać wyraźnie, że siedmiu braci męczenników może być postrzeganych jako typ Chrystusa. Liczba siedem, określająca ich ilość, jest typem doskonałości osoby Chrystusa; pochodzenie siedmiu braci od Abrahama typem pochodzenia Chrystusa; kierowanie się przez braci „pobożnym rozumem” - typem poddania się woli Ojca przez Chrystusa; namowy Antiocha IV - typem kuszenia Chrystusa przez diabła; męczeńska ofiara braci - typem ofiary zbawczej Chrystusa; „utwierdzenie w niebie" braci - typem wniebowstąpienia Chrystusa. Posługując się cytowanym wyżej stwierdzeniem św. Ireneusza, można powiedzieć, że rzeczywiście w Czwartej Księdze Machabejskiej ukryty jest Chrystus za pomocą typów, które związane są z postaciami siedmiu braci machabejskich. Mając natomiast na uwadze fakt, że Czwarta Księga Machabejska czerpała z Drugiej Księgi Machabejskiej lub z tych samych źródeł, można stwierdzić, iż sposób przedstawienia przez autora z I wieku po Chrystusie siedmiu braci, których historia rozegrała się w II wieku przed Chrystusem, jeszcze bardziej - w perspektywie typologicznej - przybliżył ich do osoby Chrystusa. W tym kontekście na uwagę zasługuje także matka siedmiu braci, której osobę można byłoby zinterpretować jako typ Maryi - Matki Chrystusa.

Słowa kluczowe: Czwarta Księga Machabejska; bracia machabejscy; egzegeza typologiczna

\section{The Seven Maccabean Brothers from The Fourth Book of Maccabees as Type of Christ. An Attempt of Applying Typological Exegesis to the Text 4 Macc.}

(summary)

As it was said at the beginning, this article presents a kind of attempt of applying typological exegesis to the text of 4 Macc. In the light of the analyzes carried out, it is clear that 
the seven martyr brothers can be seen as a type of Christ: a number seven, determining number of brothers - the type of perfection of the person of Christ; the origin of the seven brothers from Abraham - the type of origin of Christ; directing by the brothers "pious reason" - the type of surrendering to the Father's will through Christ; persuasion of Antiochus IV - the type of Christ's temptation by the devil; the martyr's sacrifice/victim of the brothers - the type of saving sacrifice of Christ; "established in heaven" brothers - the type of Christ's ascension. Bearing in mind that 4 Macc. drew from 2 Macc. or from the same sources, one can state that the manner of presenting the seven brothers by the author of the first century AD, whose history took place in the second century BC, even more - in a typological perspective - brought them closer to the person of Christ. In this context, the mother of seven brothers deserves attention, whose person could be interpreted as a type of Mary - Mother of Christ.

Keywords: The Fourth Book of Maccabees; Maccabean brothers; typological exegesis

\section{Bibliografia}

Arystoteles, Etyka Nikomachejska, tt. D. Gromska, Warszawa 2008.

Anderson H., 4 Maccabees. A New Translation and Introduction, w: The Old Testament

Pseudepigrapha, vol. 2, An Anchor Bible Reference Library, red. J.H. Charlesworth,

New York 1985, 531-564.

Baran G.M., Czwarta Księga Machabejska ttem Mowy XV św. Grzegorza z Nazjanzu, VoxP 37 (2017) t. 67, 41-70.

Baran G.M., Karanie narodu żydowskiego przez Boga jako wymiar Bożej $\pi \alpha 1 \delta \varepsilon i ́ \alpha$ wedtug Drugiej Księgi Machabejskiej, SSHT 49 (2016) z. 2, 408-429.

Baran G.M., Życie i śmierć Antiocha IV Epifanesa $w$ przekazach pozabiblijnych i biblijnych. Historia i teologia, Tarnów 2015.

Bardski K., Słowo oczyma Gołębicy. Metodologia symboliczno-alegorycznej interpretacji Biblii oraz jej teologiczne i duszpasterskie zastosowanie, Rozprawy naukowe 3, Warszawa 2007.

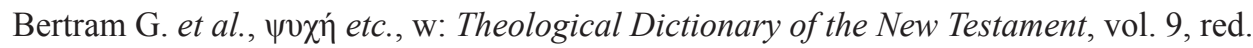

G. Friedrich, tł. G.W. Bromiley, Grand Rapids 1984, 608-666.

Breitenstein U., Beobachtungen zu Sprache, Stile und Gedankengut des Vierten Makkabäerbuchs, Basel - Stuttgart 1976.

Brzegowy T., Księgi historyczne Starego Testamentu, Academica 32, Tarnów 2008.

Crouzel H., Orygenes, tł. J. Margański, Kraków 2004.

Domaradzki M., Między alegoria a typologia. Uwagi o hermeneutyce Orygenesa, PrzRel 239 (2011) z. 1, 17-27.

Dupont-Sommer A., Le Quatrième livre des Machabées. Introduction, traduction et notes, Paris 1939.

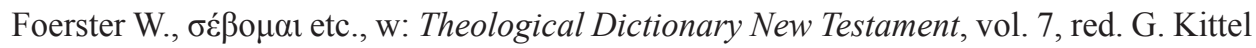
- G. Friedrich, tł. G.W. Bromiley, Grand Rapids 1983, 168-196. 
Goldstein J.A., I Maccabees. A New Translation with Introduction and Commentary, The Anchor Bible 41, Garden City - New York 1976.

Gryglewicz F., Księgi Machabejskie. Wstęp - przekład z oryginału - komentarz, Pismo Święte Starego Testamentu VI/4, Poznań 1961.

Hadas M., The Third and Fourth Books of Maccabees, Jewish Apocryphal Literature 2, New York 1953.

Hahn S., Moc słowa $w$ liturgii. Od tekstu pisanego do żywego stowa liturgii, tł. P. Blumczyński, Kraków 2010.

Henten J.W. van, The Maccabean Martyrs as Saviours of the Jewish People. A Study of 2 and 4 Maccabees, Supplements to the Journal for the Study of Judaism 57, Leiden 1997.

Homerski J., Cierpiacy wybawca i orędownik (Analiza egzegetyczno-teologiczna perykopy Iz 52,13-53,12), RTK 24 (1977) z. 4, 75-90.

Homerski J., Cierpiacy Mesjasz w starotestamentalnych przepowiedniach prorockich, RTK 27 (1980) z. 1, 27-42.

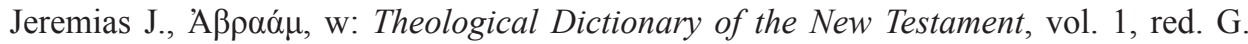
Kittel, tt. G.W. Bromiley, Grand Rapids 1983, 8-9.

Jurewicz O., Słownik grecko-polski, t. 1-2, Warszawa 2000-2001.

Knight G.A.F., Arka, tł. J. Marzęcki, w: Słownik wiedzy biblijnej, Seria biblijna „Vocatio”, red. B.M. Metzger - M.D. Coogan, Warszawa 1996, 40-41.

Klauck H.-J., 4. Makkabäerbuch, Jüdische Schriften aus hellenistisch-römischer Zeit III/6, Gütersloh 1989.

Klauck H.-J., Brotherly Love in Plutarch and in 4 Maccabees, w: Greeks, Romans, and Christians. Essays in Honor of Abraham J. Malherba, red. D.L. Balch - E. Ferguson - W.A. Meeks, Minneapolis 1990, 144-156.

Kocur M., Teatr antycznej Grecji, Dramat - Teatr 2, Wrocław 2001.

Koehler L. - Baumgartner W. - Stamm J.J., Wielki słownik hebrajsko-polski i aramejsko-polski, t. 1-2, Prymasowska Seria Biblijna, red. wyd. pol. P. Dec, Warszawa 2008.

Laskowski Ł., Druga Księga Machabejska. Wstęp, przekład z oryginału, komentarz, Nowy Komentarz Biblijny. Stary Testament XIV/3, Częstochowa 2017.

Liddell H.G. - Scott R. - Jones H.S., Greek-English Lexicon with a Revised Supplement, Oxford 1968.

Lurker M., Słownik obrazów i symboli biblijnych, tł. K. Romaniuk, Poznań 1989.

Luz U. - Koester H., Matthew 1-7. A Commentary on Matthew 1-7, Hermeneia - a Critical and Historical Commentary on the Bible, Minneapolis 2007.

Łabuda Ł, Septuaginta - pragnienie poznania Biblii, TST 35 (2016) z. 1, 161-176.

Mała Encyklopedia Kultury antycznej, red. Z. Piszczek, Warszawa 1988.

McNeil B., Typologia, w: Słownik hermeneutyki biblijnej, red. R.J. Coggins - J.L. Houlden, tł. B. Widła, Warszawa 2005, 894-894.

Mielcarek K., Ku nowej koncepcji natchnienia LXX, RT 48 (2001) z. 1, 5-25.

Muraoka T., A Greek-English Lexicon of the Septuagint, Louvain - Paris - Walpole 2009. 
O'Hagan A.P., The Martyr in the Fourth Book of Maccabees, „Liber Annuus. Studium Biblicum Franciscanum" 24 (1974) 94-120.

Paciorek A., Ewangelia wedtug świętego Mateusza. Cześć 1. Rozdziały 1-13, Nowy Komentarz Biblijny. Nowy Testament I/1, Częstochowa 2005.

Pope M.H., Seven, seventh, seventy, w: The Interpreter's Dictionary of the Bible. An Illustrated Encyclopedia, vol. 4, red. G.A. Buttrick et al., New York - Nashville 1962, 294-295.

Potterie J. de la, Czytanie Pisma Świętego „,w Duchu”: Czy możliwe jest obecnie patrystyczne czytanie Biblii?, tł. L. Balter, „Communio. Międzynarodowy Przegląd Teologiczny" 4 (1986) z. 3, 42-57.

Pytel J.K., Objaśnienie sensu biblijnego w Kościele (Hermeneutyka), Gniezno 1996.

Rigaux B. - Grelot P., Antychryst, w: Stownik teologii biblijnej, red. X. Léon-Dufour, tł. K. Romaniuk, Poznań 1994, 52-54.

Ryken L. - Wilhoit J.C. - Longman III T., Słownik symboliki biblijnej. Obrazy, symbole, motywy, metafory, figury stylistyczne i gatunki literackie w Piśmie Świętym, Prymasowska Seria Biblijna, tł. Z. Kościuk, Warszawa 1998.

Scarpat G., Quatro libro dei Maccabei. Testo, trduzione, introduzione e commento, Biblica Testi e Studi 9, nota storica G. Firpo, Brescia 2006.

Septuaginta. Id est Vetus Testamentum graece iuxta LXX interpretes. Duo volumina in uno, wyd. A. Rahlfs, Stuttgart 1982.

Silva D.A. de, 4 Maccabees, Guides to Apocrypha and Pseudepigrapha, Sheffield 1998.

Silva D.A. de, 4 Maccabees. Introduction and Commentary on the Greek Text in Codex Sinaiticus, Septuagint Commentary Series, Leiden - Boston 2006.

Simon M., Cywilizacja wczesnego chrześcijaństwa, tł. E. Bąkowska, Warszawa 1992.

Sobór Watykański II. Konstytucje, Dekrety, Deklaracje. Tekst tacińsko-polski, Poznań 2008.

Stachowiak L., Księga Izajasza II-III. 40-66. Wstęp - przekład z oryginału - komentarz ekskursy, Pismo Święte Starego Testamentu IX/2, Poznań 1996.

Weber R., Eusebeia und Logismos. Zum philosophischen Hintergrund von 4 Makkabäer, „Journal for the Study of Judaism” 22 (1991) z. 2, 212-234.

Wojciechowski M., Apokryfy z Biblii greckiej. 3 i 4 Księga Machabejska, 3 Księga Ezdrasza oraz Psalm 151 i Modlitwa Manassesa, Rozprawy i Studia Biblijne 8, Warszawa 2001. 
